Economic and Industrial Democracy

\title{
Collective bargaining coverage, works councils and the new German minimum wage
}

(C) The Author(s) 2018 Reprints and permissions: sagepub.co.uk/journalsPermissions.nav DOI: I0.1 I77/0|4383|X|8762304 journals.sagepub.com/home/eid

@SAGE

\section{Lutz Bellmann}

Institute for Employment Research (IAB), Germany; Friedrich-Alexander-University of Erlangen-Nuremberg, Germany

\section{Mario Bossler}

Institute for Employment Research (IAB), Germany; Labour and Socio-Economic Research Centre Nuremberg (LASER), Germany

\section{Hans-Dieter Gerner}

Nuremberg Institute of Technology Georg Simon Ohm, Germany; Institute for Employment Research (IAB), Germany

\section{Olaf Hübler}

Leibniz University Hannover, Germany

\begin{abstract}
This article assesses the role of the recent introduction of the minimum wage for collective bargaining coverage and works councils in Germany. The new minimum wage was initiated to strengthen German tariff autonomy, but effects on collective bargaining coverage are theoretically ambivalent. Using the IAB Establishment Panel, descriptive regressions show that firms covered by a collective bargaining contract are much less likely affected by the minimum wage. To construct a counterfactual for the group of affected establishments, the authors apply an entropy balancing procedure. Subsequent difference-in-differences estimates reveal a slight decline in collective bargaining participation, which falls short of statistical significance. Although the effect on opting into collective bargaining is even slightly positive, the authors observe a significant decrease in coverage through firms that exit collective agreements.
\end{abstract}

\section{Keywords}

Collective bargaining, industrial relations, works councils

\section{Corresponding author:}

Mario Bossler, Institute for Employment Research, Regensburger Str. 104, Nuremberg, 90478, Germany.

Email: mario.bossler@iab.de 


\section{Introduction}

Collective bargaining is a traditional institution for wage setting in Germany. It describes a system in which employer associations and unions bargain over wages for all employees at the respective firms irrespective of individual union membership. Collective bargaining is ascribed some economically desirable characteristics: it reduces transaction costs of wage negotiation and reduces the potential for conflicts between single employers and employees as it regulates the wage setting in a transparent manner. However, the benefits are challenged by growing international competition and technological change. These developments lead to a rising demand for more flexible and tailor-made compensation systems, and hence the respective firms opt out of traditional collective bargaining (Oberfichtner and Schnabel, 2017).

According to empirical analyses, the traditional German system of collective bargaining still exists in large manufacturing firms located mostly in western Germany (Oberfichtner and Schnabel, 2017). However, a general decrease in collective bargaining coverage over the last two decades is also very well documented (e.g. Addison et al., 2011). Figure 1 shows this trend in a descriptive time series for the period from 1996 to 2014. Although more than $65 \%$ of the workforce was covered by collective bargaining in the late $1990 \mathrm{~s}$, this rate fell to below 50\% more recently. This severe deterioration of a fundamental wage setting institution weakens the power of collective bargaining as a central institution for wage setting in Germany.

In addition to the political goal to support the poor and to limit the steadily increasing wage inequality, the new statutory minimum wage of $€ 8.50$ was introduced on 1 January 2015 to revert the development of decreasing collective bargaining coverage. In fact, the legal framework of the minimum wage legislation was coined the 'law to strengthen the

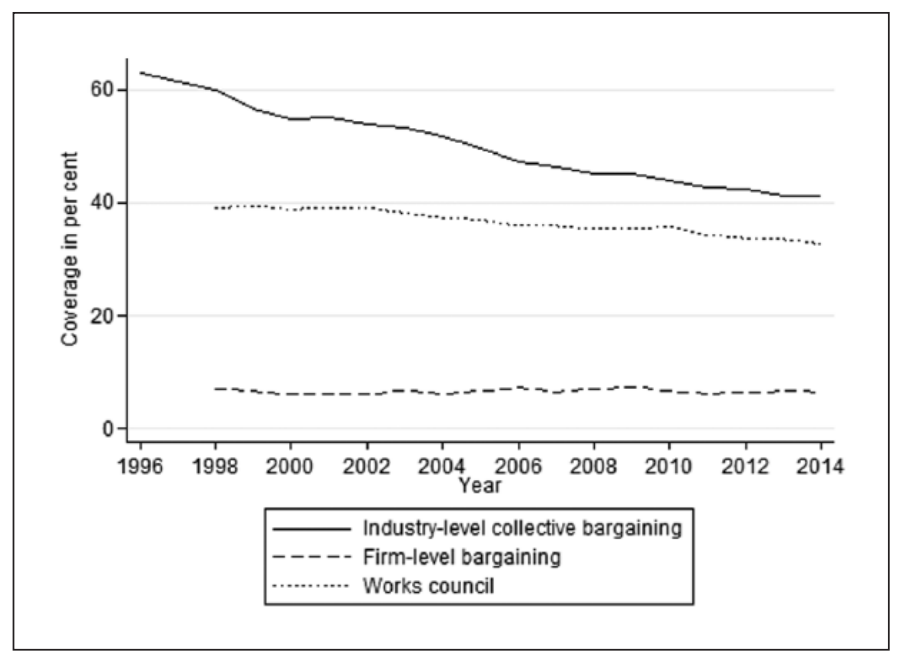

Figure I. Institutions of industrial relations in Germany.

Notes: Employee-weighted average existence of the respective institutions.

Source: IAB Establishment Panel 1996-20I4. 
tariff autonomy' (Tarifautonomiestärkungsgesetz), and the federal government's official parliamentary justification for the new law was grounded on an argumentation to strengthen the traditional tariff autonomy since contracts between bargaining partners have steadily lost their normative power (Federal Government, 2014).

Theoretically, the minimum wage could indeed influence the bargaining over wages and strengthen the position of unions. This is because both parties bargain over a surplus and the minimum wage sets a lower limit for the bargaining result. If this lower limit is a reference point and potentially a fallback position for unions, it could influence the bargained wage in the employees' favour (Apel et al., 2012; Avouyi-Dovi et al., 2013; Dittrich et al., 2014).

However, it is theoretically ambivalent whether the new minimum wage leads to a rise or a further deterioration of employers' collective bargaining participation. On the one hand, the number of firms participating in collective bargaining may rise as the minimum wage lowers the marginal costs of participation. The minimum wage sets a new minimum that is paid by all employers. Hence, additional wage costs of firms that consider an adoption of collective agreements are limited to the difference between collectively bargained wages and the minimum wage. Before the introduction of the minimum wage, these marginal wage costs of joining a collective agreement may have exceeded this difference.

On the other hand, the marginal returns of collective bargaining may also fall in the course of the introduction of the minimum wage, which induces the incentive to leave collective agreements. The reduction of marginal returns is mostly because minimum wages impose an alternative minimum standard and thereby reduce the need to bargain over wages of minimum wage jobs. Hence, the minimum wage limits the potential of collective agreements to serve as a tool to reduce the transactional costs of wage bargaining. This latter argument is in line with the theoretical explanation proposed by Aghion et al. (2011), who suggest that minimum wages crowd out industrial relations.

Since marginal costs and marginal returns are reduced by the introduction of a minimum wage, the resulting effect on employer participation is ultimately an empirical question that can be analysed in a reduced form analysis. We provide a first empirical investigation by estimating the effect of the introduction of the German minimum wage on employer participation in collective bargaining, which also contributes to a highly relevant policy question, mostly because the parliamentary justification of the new law was substitutive by design, i.e. the minimum wage was introduced to compensate for the employers' decreasing bargaining participation.

The article proceeds as follows: the second section describes the data for our analysis. The third section shows how the establishment-level bite of the minimum wage differs in the presence of collective bargaining and works councils. The fourth section evaluates the effect of the minimum wage on collective bargaining participation. The fifth concludes.

\section{Data}

The data source for our analysis is the IAB Establishment Panel, which is a large annual panel survey on general firm policies and personnel developments in Germany. The IAB 
Table I. Sample description.

\begin{tabular}{|c|c|c|c|}
\hline & \multirow{2}{*}{$\frac{(\mathrm{I})}{\text { Full sample }}$} & \multirow{2}{*}{$\frac{(2)}{\text { Affected }}$} & \multirow{2}{*}{$\frac{(3)}{\text { Unaffected establishments }}$} \\
\hline & & & \\
\hline \multirow[t]{2}{*}{ Number of establishments } & 13,794 & 2228 & 11,566 \\
\hline & $100 \%$ & $16.2 \%$ & $83.8 \%$ \\
\hline \multicolumn{4}{|l|}{ IR variables: } \\
\hline Works council & $23.9 \%$ & $13.4 \%$ & $25.9 \%$ \\
\hline Industry-level bargaining & $32.5 \%$ & $19.3 \%$ & $35.0 \%$ \\
\hline Firm-level bargaining & $5.9 \%$ & $3.6 \%$ & $6.4 \%$ \\
\hline Alignment & $30.2 \%$ & $32.2 \%$ & $29.8 \%$ \\
\hline
\end{tabular}

Source: IAB Establishment Panel 20I4, analysis sample.

Establishment Panel covers between 15,000 and 16,000 establishment observations each year since 1993. ${ }^{1}$ The survey's gross population units are all establishments located in Germany with at least one employee liable to social security. The data are representative for German states (Bundesländer), industries and establishment size. Interviews are conducted face-to-face by professional interviewers, which ensures a high data quality and a panel continuation rate of about $83 \%$. More comprehensive data descriptions of the IAB Establishment Panel can be found in Ellguth et al. (2014b) or Fischer et al. (2009).

The 2014 cross-section of the IAB Establishment Panel, which is before the minimum wage was introduced, allows to distinguish between affected and unaffected establishments. The survey includes information on the extensive bite of the minimum wage, i.e. whether or not an establishment is affected by the introduction of the minimum wage, by asking whether the respective establishment has at least one employee with an hourly wage below $€ 8.50$ in 2014. Moreover, it includes information on the intensity to which an establishment was affected by the introduction of the minimum wage (intensive bite) by asking for the number of affected employees with an hourly wage below $€ 8.50$. $^{2}$

A unique establishment identifier allows tracking establishments over time if the respective establishments continue to participate in the survey. For our research question of whether collective bargaining participation changes in response to the introduction of the minimum wage, the establishment identifier allows tracking establishments from the years prior to the introduction of the minimum wage to 2015 and 2016, while using the 2014 measure of whether a plant is affected by the introduction of the minimum wage to define the treatment group.

The descriptive statistics in Table 1 present a first snapshot of the analysis sample comprising all private sector establishments in Germany. We observe 13,794 establishments, of which 2228 are affected by the minimum wage and 11,566 are unaffected, as they did not have employees on wages below $€ 8.50$ in 2014 . Looking at the coverage by industrial relations, $23.9 \%$ of all establishments have a works council, $32.5 \%$ participate in industry-wide collective bargaining, and 5.9\% have a firm-level contract. The latter is a contract that is bargained between the relevant union and the respective employer only and hence it does not require membership in an employers' association. An additional 
$30.2 \%$ of the establishments do not formally participate in any kind of collective bargaining but align their wage levels to collectively bargained wages.

\section{The bite of the minimum wage}

Before analysing the effects of the minimum wage on collective bargaining participation, we assess which kinds of establishments were affected in 2014 before the minimum wage was introduced. The definition of affected establishments is important as it differentiates a treated group of establishments from an unaffected group. It also gives an insight into the extent to which the minimum wage is binding. We expect that affected establishments react in response to the minimum wage since they have to adjust wages to comply with the law, but they may also adopt other establishment-level measures to cope with the increased wage costs.

Most of the existing empirical evidence on the scope of the new minimum wage in Germany is based on employee data. Brenke and Müller (2013), Kalina and Weinkopf (2013), Heumer et al. (2013), Falck et al. (2013) and Knabe et al. (2014) predict the number of affected employees from individual survey data using previous waves of the German Socio-Economic Panel (SOEP) and Knabe et al. use this number to simulate potential effects on employment. Their results reveal a relatively higher bite in eastern Germany compared with states in the west. In eastern Germany, the fraction of affected employees is between $20 \%$ according to the study of Knabe et al. (2014) and $32 \%$ according to the studies conducted by Kalina and Weinkopf (2013) and Heumer et al. (2013). By contrast, in western Germany between 13\% according to Knabe et al. (2014) and 18\% according to Kalina and Weinkopf (2013) are affected.

The IAB Establishment Panel allows a comprehensive assessment of affected workplaces, i.e. from an employer perspective. As displayed in Table 1, 16.2\% of establishments are affected by the minimum wage. Moreover, we know from the literature that affected establishments also show a large bite of the minimum wage in terms of intensity (Bellmann et al., 2015), making reactions to the minimum wage likely as wage costs vastly increase.

Since we are especially interested in the role of industrial relations, we want to know to what extent firms with works councils and collective bargaining are affected differently by the minimum wage compared with firms at which such institutions are absent. We expect a lower bite if a firm is covered by industry-wide collective bargaining since such firms are typically characterized by higher wages (e.g. Addison et al., 2014). We could also expect that firms with works councils have a higher bite because works councils are primarily representatives of the core workforce and less so for the marginal workforce. As marginal employees are most severely affected by the minimum wage (Falck et al., 2013), we would expect a negative correlation between the bite of the minimum wage and the existence of works councils. However, works councils are also known to have a positive impact on productivity and wages (Addison et al., 2010; Ellguth et al., 2014a; Hübler and Jirjahn, 2003; Müller, 2012). In this respect, the bite of the minimum wage should be lower in establishments with a works council. 
Table 2. Industrial relations and the establishment-level bite.

\begin{tabular}{|c|c|c|c|c|c|c|}
\hline & \multirow{2}{*}{$\begin{array}{l}\text { (I) } \\
\begin{array}{l}\text { Full sample } \\
\text { (OLS) }\end{array}\end{array}$} & \multirow{2}{*}{$\frac{(2)}{\begin{array}{l}\text { Full sample } \\
\text { (probit) }\end{array}}$} & \multirow{2}{*}{$\begin{array}{l}(3) \\
\text { Eastern } \\
\text { Germany } \\
\text { (OLS) }\end{array}$} & \multirow{2}{*}{$\begin{array}{l}(4) \\
\text { Eastern } \\
\text { Germany } \\
\text { (probit) }\end{array}$} & \multirow{2}{*}{$\begin{array}{l}(5) \\
\text { Western } \\
\text { Germany } \\
(O L S)\end{array}$} & \multirow{2}{*}{$\begin{array}{l}(6) \\
\text { Western } \\
\text { Germany } \\
\text { (probit) }\end{array}$} \\
\hline & & & & & & \\
\hline \multirow{2}{*}{$\begin{array}{l}\text { Ind.-level } \\
\text { barg. }\end{array}$} & $-0.097^{\text {*ak }}$ & $-0.097^{\text {*冰 }}$ & $-0.160^{* \text { *ak }}$ & $-0.176^{* * *}$ & $-0.040^{\text {**** }}$ & 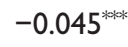 \\
\hline & $(0.008)$ & $(0.008)$ & $(0.016)$ & $(0.017)$ & $(0.009)$ & $(0.009)$ \\
\hline \multirow{2}{*}{$\begin{array}{l}\text { Firm-level } \\
\text { barg. }\end{array}$} & $-0.116^{* \text { *⿻丷木 }}$ & 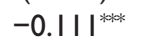 & $-0.178^{* * \alpha *}$ & $-0.191^{* * * *}$ & $-0.042^{* * * *}$ & $-0.05 I^{\text {*⿻丷木大巾 }}$ \\
\hline & $(0.013)$ & $(0.014)$ & $(0.022)$ & $(0.027)$ & $(0.014)$ & $(0.016)$ \\
\hline \multirow[t]{2}{*}{ Alignment } & 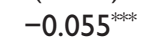 & $-0.042^{* * *}$ & $-\left.0.09\right|^{* * 2 k}$ & $-0.08 I^{* * * *}$ & -0.010 & -0.011 \\
\hline & $(0.008)$ & $(0.007)$ & $(0.013)$ & $(0.012)$ & $(0.009)$ & $(0.008)$ \\
\hline \multirow{2}{*}{$\begin{array}{l}\text { Works } \\
\text { council }\end{array}$} & $-0.070^{\text {topok }}$ & $-0.067^{* a k k}$ & $-0.112^{* w a k}$ & $-0.108^{* * * *}$ & $-0.04 I^{* ⿰ \alpha+k}$ & $-0.042^{\text {*atek }}$ \\
\hline & $(0.009)$ & $(0.010)$ & $(0.019)$ & $(0.019)$ & $(0.010)$ & $(0.010)$ \\
\hline \multicolumn{2}{|c|}{ Observations 13,794} & 13,794 & 5439 & 5439 & 8355 & 8355 \\
\hline
\end{tabular}

Notes: Reported coefficients are average partial effects from linear OLS and non-linear probit estimations. The dependent variable is a dummy that indicates whether the establishment is affected by the minimum wage. Robust standard errors are in parentheses. Asterisks indicate significance levels: $*_{p}<0.1, *_{p}<0.05$ and $* * * p<0.01$.

Source: IAB Establishment Panel 20I4, analysis sample.

Table 2 presents average partial effects of these institutions on the establishmentlevel bite from OLS and probit estimations applied to data from 2014. In multivariate regression models, we account for the correlation between the bite measure and sector, location, size and other covariates including shares of females, highly qualified, medium qualified and part-time employees, as well as dummies for firm age, product market competition, innovative activities, legal form and whether the establishment is a single entity. This also controls for potentially selective foundation of works councils in an establisment with respect to firm and workforce characteristics (Oberfichtner, 2016).

Looking at the full sample in columns (1) and (2) of Table 2, the estimates show negative and significant average partial effects of collective bargaining and the existence of a works council on whether a firm is affected by the minimum wage. ${ }^{3}$ Moreover, establishments that are not directly covered by collective bargaining but instead align wage levels to collectively bargained wage levels are less likely affected. This demonstrates that the scope of industry-wide collective bargaining goes beyond the formally covered firms. These negative conditional correlations of industrial relations and the firms' likelihood to be affected by the minimum wage are much stronger in eastern Germany (columns 3 and 4) than in western Germany (columns 5 and 6). In the west, the average partial effects of collective bargaining contracts and works councils are still significantly negative, but they become insignificant for firms that report alignment to collective bargaining contracts. 
Table 3. Industrial relations and the employee-level bite.

\begin{tabular}{|c|c|c|c|c|c|c|}
\hline & \multirow{2}{*}{$\begin{array}{l}(\mathrm{I}) \\
\text { Full sample } \\
(\mathrm{OLS})\end{array}$} & \multirow{2}{*}{$\begin{array}{l}\text { (2) } \\
\text { Full sample } \\
\text { (frac. probit) }\end{array}$} & \multirow{2}{*}{$\begin{array}{l}(3) \\
\text { Eastern } \\
\text { Germany } \\
\text { (OLS) }\end{array}$} & \multirow{2}{*}{$\begin{array}{l}(4) \\
\text { Eastern } \\
\text { Germany } \\
\text { (frac. probit) }\end{array}$} & \multirow{2}{*}{$\begin{array}{l}(5) \\
\text { Western } \\
\text { Germany } \\
\text { (OLS) }\end{array}$} & \multirow{2}{*}{$\begin{array}{l}\text { (6) } \\
\text { Western } \\
\text { Germany } \\
\text { (frac. probit) }\end{array}$} \\
\hline & & & & & & \\
\hline \multirow{2}{*}{$\begin{array}{l}\text { Ind.-level } \\
\text { barg. }\end{array}$} & $-0.035^{* * *}$ & $-0.034^{* 2 * k}$ & 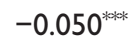 & $-0.062^{\text {*ak }}$ & $-0.015^{\text {*a*k }}$ & $-0.013^{* * * *}$ \\
\hline & $(0.004)$ & $(0.004)$ & $(0.008)$ & $(0.009)$ & $(0.004)$ & $(0.003)$ \\
\hline \multirow{2}{*}{$\begin{array}{l}\text { Firm-level } \\
\text { barg. }\end{array}$} & $-0.042^{* * * k}$ & $-0.035^{* \text { *ak }}$ & $-0.054^{*}$ & $-0.068^{* 0 * k}$ & $-0.014^{* 01 \%}$ & $-0.013^{* *}$ \\
\hline & $(0.005)$ & $(0.007)$ & $(0.010)$ & $(0.015)$ & $(0.005)$ & $(0.006)$ \\
\hline \multirow[t]{2}{*}{ Alignment } & $-0.029^{\text {***⿰㇇⿰亅⿱丿丶丶 }}$ & $-0.020^{* * * *}$ & $-0.043^{\text {*ak }}$ & $-0.039^{* * * *}$ & $-0.009^{* * *}$ & $-0.006^{* *}$ \\
\hline & $(0.004)$ & $(0.003)$ & $(0.007)$ & $(0.006)$ & $(0.004)$ & $(0.003)$ \\
\hline \multirow{2}{*}{$\begin{array}{l}\text { Works } \\
\text { council }\end{array}$} & 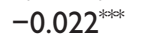 & $-0.036^{* * * *}$ & $-0.048^{\text {*wk }}$ & $-0.066^{\text {*a冰 }}$ & $-0.008^{\text {*a*k }}$ & $-0.017^{* * * *}$ \\
\hline & $(0.004)$ & $(0.005)$ & $(0.008)$ & $(0.011)$ & $(0.003)$ & $(0.004)$ \\
\hline \multicolumn{2}{|c|}{ Observations 13,794 } & 13,794 & 5439 & 5439 & 8355 & 8355 \\
\hline
\end{tabular}

Notes: Reported coefficients are average partial effects from linear OLS and non-linear fractional probit estimations. The dependent variable is the fraction of affected employees. Robust standard errors are in parentheses. Asterisks indicate significance levels: $*_{p}<0.1$, $* * p<0.05$ and $*_{* *} * 0.0$ I.

Source: IAB Establishment Panel 20I4, analysis sample.

In Table 3, the dependent variable further differentiates by the proportion of affected employees. The OLS and fractional probit estimations reveal highly significant and negative average partial effects of the measures representing industrial relations in the German labour market. This negative relationship is again much stronger in eastern Germany compared with firms in the west (columns 3-6). ${ }^{4}$

\section{Minimum wage effect on collective bargaining coverage}

In the remaining analysis, we concentrate on the effects of the minimum wage on collective bargaining coverage. From a theoretical perspective, both increasing and decreasing collective bargaining coverage is possible when an establishment is affected by the minimum wage. Establishments may join collective bargaining as the additional/marginal labour costs of joining collective bargaining are reduced to the difference between collectively bargained wages and the minimum wage. On the other hand, the marginal returns from participation in collective bargaining contracts are also reduced, which may encourage firms to opt out of collective bargaining contracts. Firms with a works council may have a collective voice that prevents employers from leaving collective bargaining. Moreover, firms with a works council may be less interested in leaving collective bargaining because collective bargaining strengthens the effectiveness of performanceenhancing work practices from negotiations between the management and the works council (Jirjahn, 2017). 


\section{Empirical identification strategy}

In our empirical analysis, we rely on a difference-in-differences estimation, which yields a treatment effect on the treated establishments from a treatment group and treatment time interaction. In our analysis, the treatment time comprises the years following the introduction of the minimum wage, which are 2015 and 2016, and firms that are treated by the minimum wage were affected according to the 2014 survey information.

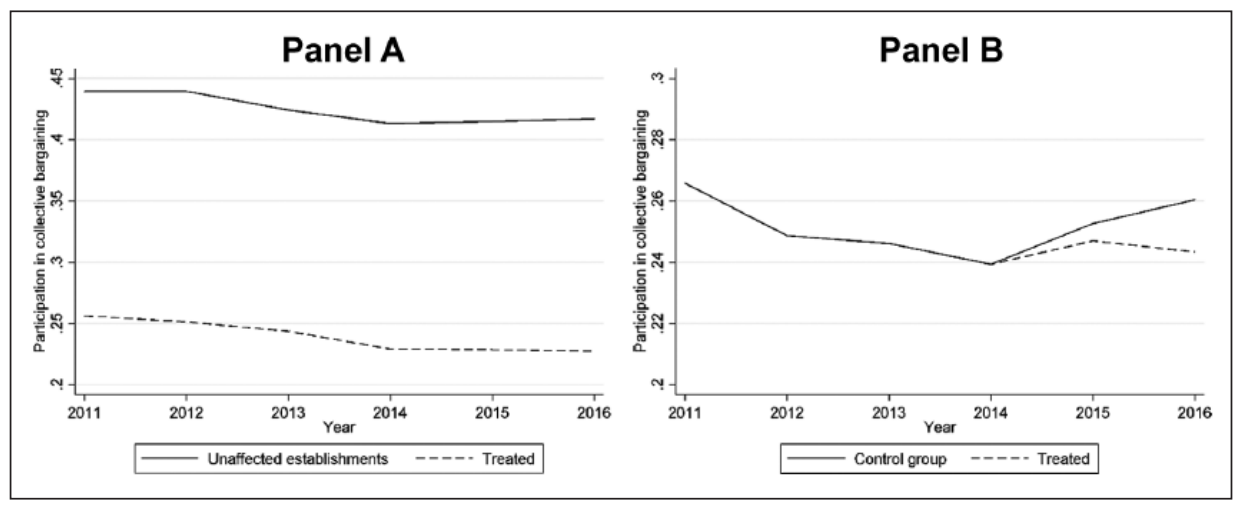

Figure 2. Collective bargaining at treated and unaffected establishments.

Panel A: Raw time series.

Panel B: Time series after entropy balancing.

Notes: Time series of average participation in collective bargaining for treated establishments and the raw group of unaffected establishments in Panel A. Time series of average participation in collective bargaining for treated establishments and a weighted control group from entropy balancing in Panel B.

Source: IAB Establishment Panel 20I I-20I4, analysis sample.

The most crucial assumption of the difference-in-differences estimation are parallel trends between treatment and control groups. As presented in the previous section, we observe large level-differences in collective bargaining by whether the minimum wage is binding to a particular establishment. The likelihood of a bargaining contract is much lower whenever an establishment is affected by the minimum wage. These large leveldifferences make it difficult to assess the parallel trends assumption, as illustrated in Panel A of Figure 2. In fact, the parallel trends assumption requires that the control group behaves as the treatment group in the absence of the introduction of the minimum wage, i.e. that the control group is a good counterfactual for the treated establishments. This similarity in the absence of the minimum wage seems much more likely whenever the control group not only resembles the trend of the treatment group but also the levels of the outcome variables.

To construct a control group that matches trends as well as levels of the treatment group before the introduction of the minimum wage, we apply the entropy balancing procedure proposed by Hainmueller (2012). This method provides weights for the group of unaffected workplaces such that the weighted control group closely matches the treatment group, as illustrated in Panel B of Figure 2. In our baseline estimation, we only use pre-treatment outcome-levels of the respective collective bargaining regime in the years 


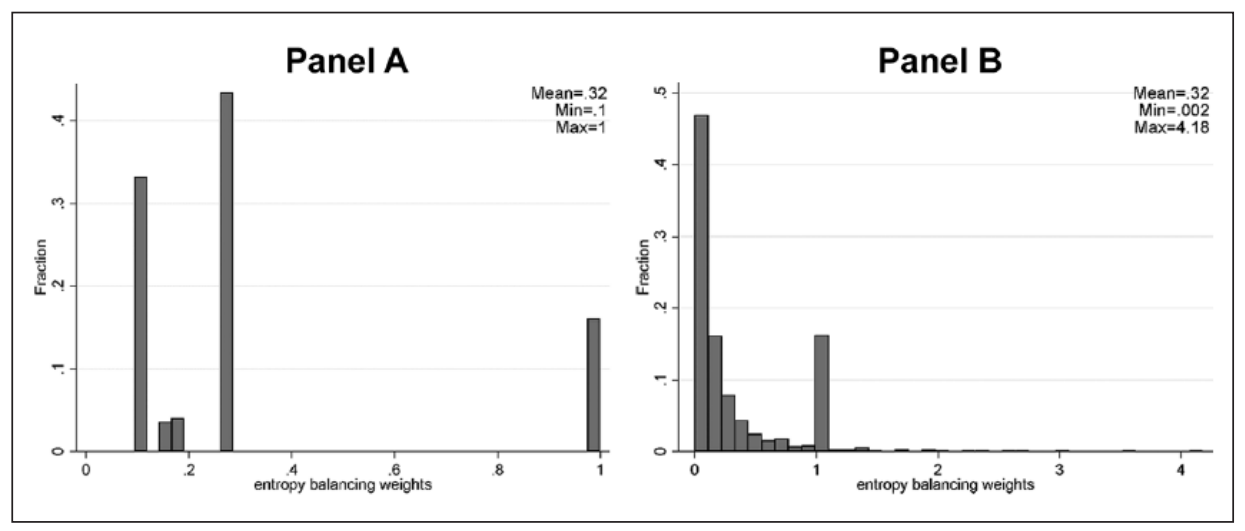

Figure 3. Histograms of entropy balancing weights in our weighted control groups.

Panel A.

Using pre-determined outcomes only.

Panel B.

Using pre-determined outcomes and additional covariates.

2011-2014 to reweight the control group..$^{5}$ In further robustness checks, we also calculate weights using balance constraints for the industry (41 categories), the initial establishment size (9 categories) and a dummy for eastern Germany. These additional covariates lead to a weighted control group in which each treated workplace is matched with a weighted control that is from within the same industry, size and region, but it also resembles the pre-treatment outcome variable in levels and trends. The distribution of weights defined from the two variants with and without the additional balancing constraints are illustrated by histograms in Figure 3. The baseline variant in Panel A shows a relatively homogeneous distribution of weights, and the more sophisticated variant in Panel B has a few more outliers due to a much larger number of balance constraints that have to be fulfilled by the weights.

The entropy balancing procedure comes with three major advantages over other matching procedures (Hainmueller, 2012). First, it results in a control group that closely resembles the treatment group of interest, i.e. the checks for parallel trends or placebo estimations become irrelevant (see Panel B of Figure 2). Second, it is computationally easy to be implemented in Stata (Hainmueller and $\mathrm{Xu}, 2013$ ). And third, the weights can be used in subsequent regression models such as the difference-in-differences approach which we apply here. In fact, we estimate a weighted difference-in-differences regression as formulated in equation (1):

$$
y_{i t}=\operatorname{tgroup}_{i} * D 2016_{t} * \delta_{2016}+\text { tgroup }_{i} * D 2015_{t} * \delta_{2015}+\operatorname{tgroup}_{i} * \beta+\gamma_{t}+\varepsilon_{i t}
$$

where the subscript $t=2011, \ldots, 2016$ describes the time dimension for each establishment $i=1, \ldots, N$ in the weighted analysis sample. The left-hand side outcome variable $y_{i t}$ describes the existence of a bargaining contract, ${ }^{6}$ where 


$$
y_{i t}=\left\{\begin{array}{cc}
1 & \text { if } i \text { participates in collective bargaining in period } t \\
0 & \text { otherwise } .
\end{array}\right.
$$

tgroup $_{i}$ is a treatment group identifier for treated establishments in the sample. D2015 and $D 2016_{t}$ are dummy variables for the years 2015 and 2016. The interaction effects of the treatment group and treatment time $\left(\delta_{2015}\right.$ and $\left.\delta_{2016}\right)$ are the treatment effects of interest for the years 2015 and 2016. We estimate the model using a level effect for the treatment group $(\beta)$ by OLS, but we also estimate establishment fixed-effects specifications, where a separate effect is estimated for every establishment in the weighted sample. Finally, all regressions include separate time effects for all years in the data and an idiosyncratic error term.

\section{Results}

The baseline results in Table 4 are displayed for three different outcome variables: presence of an industry-level bargaining contract (columns 1 and 2), presence of a firm-level bargaining contract (columns 3 and 4) and presence of any bargaining contract which is either an industry-wide or a firm-level contract (columns 5 and 6). The effects from OLS in column (1) reveal a small decline in industry-level bargaining coverage induced by the minimum wage. While the effect is still relatively small in 2015, it starts to pick up in 2016 implying a one percentage point reduction in industrylevel collective bargaining. However, the effect falls short of conventional significance

Table 4. Baseline treatment effects.

\begin{tabular}{|c|c|c|c|c|c|c|}
\hline & \multirow{2}{*}{$\begin{array}{l}(\mathrm{I}) \\
\text { Industry-level } \\
\text { bargaining } \\
\text { (OLS) }\end{array}$} & \multirow{2}{*}{$\begin{array}{l}(2) \\
\text { Industry-level } \\
\text { bargaining (FE) }\end{array}$} & \multirow{2}{*}{$\begin{array}{l}(3) \\
\text { Firm-level } \\
\text { bargaining } \\
\text { (OLS) }\end{array}$} & \multirow{2}{*}{$\begin{array}{l}(4) \\
\text { Firm-level } \\
\text { bargaining } \\
(\mathrm{FE})\end{array}$} & \multirow{2}{*}{$\begin{array}{l}(5) \\
\text { Any } \\
\text { bargaining } \\
\text { (OLS) }\end{array}$} & \multirow{2}{*}{$\begin{array}{l}(6) \\
\text { Any } \\
\text { bargaining } \\
(\mathrm{FE})\end{array}$} \\
\hline & & & & & & \\
\hline \multirow[t]{2}{*}{ Effect 2016} & -0.015 & -0.011 & -0.006 & -0.004 & -0.019 & -0.012 \\
\hline & $(0.011)$ & $(0.010)$ & $(0.006)$ & $(0.006)$ & $(0.012)$ & $(0.010)$ \\
\hline \multirow[t]{2}{*}{ Effect 2015} & -0.005 & -0.006 & -0.005 & -0.005 & -0.008 & -0.008 \\
\hline & $(0.009)$ & $(0.008)$ & $(0.005)$ & $(0.005)$ & $(0.010)$ & $(0.009)$ \\
\hline Observations & 41,133 & $4 I, 133$ & $4 I, 133$ & 41,133 & $4 \mid, 133$ & 41,133 \\
\hline Establishments & 7334 & 7334 & 7334 & 7334 & 7334 & 7334 \\
\hline Treated establ. & 1174 & 1174 & 1174 & 1174 & 1174 & 1174 \\
\hline
\end{tabular}

Notes: Reported coefficients are treatment effects on the treated establishments from weighted linear difference-in-differences estimations. Weights are retrieved from entropy balancing. The dependent variable is the participation in collective bargaining at the industry or firm level. Cluster robust standard errors are in parentheses (cluster $=$ establishment). Asterisks indicate significance levels: $*_{p}<0.1, *_{p}<0.05$ and $* * * p<0.0$ I.

Source: IAB Establishment Panel 20II-2016, weighted analysis sample after entropy balancing. 
levels. The fixed effects (FE) regression in column (2) shows a similar effect size but again lacks precision. Differences between the fixed effects and the OLS estimates can be explained by the fact that the OLS estimation also captures changes that are due to a changing establishment composition within the treatment and control groups over time, i.e. through firms leaving the market. By contrast, fixed-effects estimates only capture changes that occur within establishments.

The treatment effects on the presence of firm-level bargaining contracts are somewhat smaller in size and again imprecisely estimated but still negative. Considering that the average prevalence of firm-level bargaining contracts is quite low (Table 1), a half percentage point reduction is still economically relevant in relative terms. Looking at the combined effect in column (5) or (6) it it adds up the effects of the two specific kinds of bargaining contracts but still lacks precision. ${ }^{7}$ Nevertheless, we should emphasize that the treatment effect on the treated is plausible in size as it corresponds to the average yearly decline of all establishments in the years before the minimum wage was introduced (see Figure 1). Since the effects are relatively similar for the different kinds of bargaining, we continue our analysis with the combined measure capturing both kinds of bargaining contracts in a single variable such as in columns (5) and (6).

Table 5 presents effects of the minimum wage using additional covariates as balancing conditions in our calculation of weights for a counterfactual control group. In columns (1) and (2), we include conditions that yield a control group that is from within the same industry, the same size category and the same region (eastern/western Germany). In columns (3) and (4), the control group of establishments is calculated from additional conditions that also equalize the pre-determined workforce composition, i.e. the shares of female and part-time employees as well as the qualification shares. The estimated effects in Table 5 reveal similar effect sizes as in Table 4. Hence, the treatment effects still indicate a small negative influence of the introduction of the minimum wage. In most cases the effects fall short of conventional significance levels, but it demonstrates that the baseline estimates do not rely on the choice of variables that are used to construct the control group.

In Table 6, we look at wage effects, which are a prerequisite to detect effects in minimum wage analyses, because the presence of a wage effect ensures a binding minimum wage. Moreover, wage effects are informative as they allow us to relate the size of effects across specifications and even across studies of different minimum wages. The results in Table 6 are again structured by the kinds of covariates that have been used to construct the control group. ${ }^{8}$ In columns (1) and (2) we use the same baseline weights as in Table $4,{ }^{9}$ in columns (3) and (4) we use a control group from within the same industry, size and region, and in columns (5) and (6) the control group is also restricted to the same employee composition. It turns out that there is a robust wage effect in columns (1) to (4), but as soon as we control for additional covariates, the wage effect vanishes. ${ }^{10}$ This is because the restriction on the very same employee composition leaves very little scope for wage differences between treated and control establishments, i.e. the workplaces become too similar. Based on these wage effects, our preferred control group is within industries, size and region, as in columns (3) and (4). ${ }^{11}$ 
Table 5. Treatment effects including covariates.

\begin{tabular}{|c|c|c|c|c|}
\hline & (I) & (2) & (3) & (4) \\
\hline & Any bargaining (OLS) & $\begin{array}{l}\text { Any bargaining } \\
\text { (FE) }\end{array}$ & $\begin{array}{l}\text { Any bargaining } \\
\text { (OLS) }\end{array}$ & $\begin{array}{l}\text { Any bargaining } \\
\text { (FE) }\end{array}$ \\
\hline \multirow[t]{2}{*}{ Effect 2016} & -0.017 & -0.016 & $-0.025^{*}$ & -0.016 \\
\hline & $(0.014)$ & $(0.012)$ & $(0.015)$ & $(0.012)$ \\
\hline \multirow[t]{2}{*}{ Effect 2015} & -0.006 & -0.008 & -0.010 & -0.007 \\
\hline & $(0.011)$ & $(0.010)$ & $(0.012)$ & $(0.010)$ \\
\hline \multicolumn{5}{|l|}{ Controls: } \\
\hline Size, industry, east & Yes & Yes & Yes & Yes \\
\hline $\begin{array}{l}\text { Employee } \\
\text { composition }\end{array}$ & No & No & Yes & Yes \\
\hline Observations & 41,133 & 41,133 & 41,133 & 41,133 \\
\hline Establishments & 7334 & 7334 & 7334 & 7334 \\
\hline Treated establ. & 1174 & 1174 & 1174 & 1174 \\
\hline
\end{tabular}

Notes: Reported coefficients are treatment effects on the treated establishments from weighted linear difference-in-differences estimations. Weights are retrieved from entropy balancing. The dependent variable is the participation in collective bargaining at the industry or firm level. Cluster robust standard errors are in parentheses (cluster $=$ establishment). Asterisks indicate significance levels: $* p<0.1, * * p<0.05$ and $* * * p<0.01$.

Source: IAB Establishment Panel 20I I-2016, weighted analysis sample after entropy balancing.

Table 6. Wage effects with and without covariates.

\begin{tabular}{|c|c|c|c|c|c|c|}
\hline & \multirow{2}{*}{$\begin{array}{l}(\mathrm{I}) \\
\text { Log wages } \\
\text { without } \\
\text { covariates } \\
\text { (OLS) }\end{array}$} & \multirow{2}{*}{$\begin{array}{l}(2) \\
\text { Log wages } \\
\text { without } \\
\text { covariates } \\
(\mathrm{FE})\end{array}$} & \multirow{2}{*}{$\begin{array}{l}(3) \\
\text { Log wages } \\
\text { with } \\
\text { covariates } \\
\text { (OLS) }\end{array}$} & \multirow{2}{*}{ 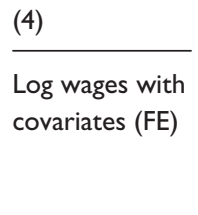 } & \multirow{2}{*}{$\begin{array}{l}(5) \\
\text { Log wages } \\
\text { with many } \\
\text { covariates } \\
\text { (OLS) }\end{array}$} & \multirow{2}{*}{$\begin{array}{l}(6) \\
\text { Log wages } \\
\text { with many } \\
\text { covariates (FE) }\end{array}$} \\
\hline & & & & & & \\
\hline \multirow[t]{2}{*}{ Effect 2016} & $0.050 * *$ & $0.055^{* * *}$ & $0.047^{* *}$ & $0.054 * * *$ & 0.005 & $0.033^{*}$ \\
\hline & $(0.022)$ & $(0.016)$ & $(0.024)$ & $(0.017)$ & $(0.026)$ & $(0.019)$ \\
\hline \multirow[t]{2}{*}{ Effect 2015} & $0.060 * * *$ & $0.063 * * *$ & $0.052^{* * * *}$ & $0.060 * * * *$ & 0.034 & $0.05 I^{* * * *}$ \\
\hline & $(0.017)$ & $(0.012)$ & $(0.019)$ & $(0.014)$ & $(0.021)$ & $(0.015)$ \\
\hline \multicolumn{7}{|l|}{ Controls: } \\
\hline Size, industry, east & No & No & Yes & Yes & Yes & Yes \\
\hline Employee comp. & No & No & No & No & Yes & Yes \\
\hline Observations & 35,059 & 35,059 & 35,059 & 35,059 & 35,059 & 35,059 \\
\hline Establishments & 6916 & 6916 & 6916 & 6916 & 6916 & 6916 \\
\hline Treated establ. & 1174 & 1174 & 1174 & 1174 & 1174 & 1174 \\
\hline
\end{tabular}

Notes: Reported coefficients are treatment effects on the treated establishments from weighted linear difference-in-differences estimations. Weights are retrieved from entropy balancing. The dependent variable is the log average wage at the workplace. Cluster robust standard errors are in parentheses (cluster $=$ establishment). Asterisks indicate significance levels: $*_{p}<0.1$, $*_{p}<0.05$ and $* * * p<0.01$.

Source: IAB Establishment Panel 20I I-2016, weighted analysis sample after entropy balancing. 


\section{Effect heterogeneities}

To detect potential treatment effect heterogeneities of the introduction of the minimum wage on the presence of a bargaining contract, we first disentangle the effect direction, i.e. we differentiate between plants that opt out of bargaining contracts and plants that adopt a bargaining contract. We achieve this distinction by restricting the sample first to establishments that were covered in the years from 2011 to 2014 and second to establishments that were not covered before the minimum wage was introduced. ${ }^{12}$

Table 7. Treatment effects by direction.

Effects through exits: Sample restricted to bargaining participants before minimum wage introduction

(I)
(2)
Effects through entries: Sample restricted to uncovered establishments before minimum wage introduction

(3)

(4)

\begin{tabular}{lllll}
\hline & $\begin{array}{l}\text { Any bargaining } \\
\text { (OLS) }\end{array}$ & $\begin{array}{l}\text { Any bargaining } \\
(\mathrm{FE})\end{array}$ & $\begin{array}{l}\text { Any bargaining } \\
(\mathrm{OLS})\end{array}$ & $\begin{array}{l}\text { Any bargaining } \\
(\mathrm{FE})\end{array}$ \\
\hline Effect 2016 & $-0.065^{* *}$ & $-0.065^{* *}$ & 0.009 & 0.009 \\
& $(0.026)$ & $(0.026)$ & $(0.01 \mathrm{I})$ & $(0.01 \mathrm{I})$ \\
Effect 2015 & $-0.044^{* *}$ & $-0.043^{* *}$ & 0.002 & 0.003 \\
& $(0.021)$ & $(0.02 \mathrm{I})$ & $(0.009)$ & $(0.009)$ \\
Observations & 14,216 & & 21,513 & \\
Establishments & 2530 & & 3829 & \\
Treated establ. & 222 & & 798 & \\
\hline
\end{tabular}

Notes: Reported coefficients are treatment effects on the treated establishments from weighted linear difference-in-differences estimations. Weights are retrieved from entropy balancing. The dependent variable is the participation in collective bargaining at the industry or firm level. Control variables as in columns (I) and (2) of Table 5. Cluster robust standard errors are in parentheses (cluster $=$ establishment). Asterisks indicate significance levels: $* p<0.1$, **p $<0.05$ and $* * * p<0.01$.

Source: IAB Establishment Panel 20I I-2016, weighted analysis sample after entropy balancing, comprising of firms that initially participated in collective bargaining (in columns I and 2) and firms that initially did not participate in collective bargaining (in columns 3 and 4).

The effects in Table 7 show that a significant fraction of treated establishments leave collective bargaining due to the minimum wage (columns 1 and 2), but a small fraction also adopt bargaining contracts (columns 3 and 4). Since the latter effect is smaller and again statistically insignificant, both results in combination can explain the slight negative overall effect presented above.

Further effect heterogeneities are presented in Table 8. In the first column, we analyse the alignment to collective bargaining without any formal contract. Although collective bargaining coverage decreased over the last two decades in Germany, an increasing number of establishments align wages to collectively bargained wage levels without a formal commitment (Addison et al., 2016; Bossler, 2017). This alignment to 
Table 8. Further treatment effect heterogeneities.

\begin{tabular}{|c|c|c|c|c|c|c|}
\hline & \multirow{2}{*}{$\begin{array}{l}\text { (I) } \\
\text { Alignment } \\
\text { to CB, full } \\
\text { sample }\end{array}$} & \multirow{2}{*}{$\begin{array}{l}(2) \\
\text { Wages } \\
\text { exceeding } \\
\text { CB, full } \\
\text { sample }\end{array}$} & \multirow{2}{*}{$\begin{array}{l}(3) \\
\text { Any } \\
\text { bargaining, } \\
\text { western } \\
\text { Germany }\end{array}$} & \multirow{2}{*}{$\begin{array}{l}(4) \\
\text { Any } \\
\text { bargaining, } \\
\text { eastern } \\
\text { Germany }\end{array}$} & \multirow{2}{*}{$\begin{array}{l}(5) \\
\text { Any } \\
\text { bargaining, } \\
\text { works } \\
\text { council }\end{array}$} & \multirow{2}{*}{$\begin{array}{l}(6) \\
\text { Any bargaining, } \\
\text { no works } \\
\text { council }\end{array}$} \\
\hline & & & & & & \\
\hline \multirow[t]{2}{*}{ Effect 2016} & 0.013 & -0.006 & -0.033 & -0.008 & -0.023 & -0.007 \\
\hline & $(0.016)$ & $(0.010)$ & $(0.021)$ & $(0.014)$ & $(0.034)$ & $(0.013)$ \\
\hline \multirow[t]{2}{*}{ Effect 2015} & 0.001 & -0.003 & -0.010 & -0.008 & -0.031 & -0.002 \\
\hline & $(0.015)$ & $(0.009)$ & $(0.016)$ & $(0.012)$ & $(0.029)$ & $(0.011)$ \\
\hline Observations & 41,133 & 41,133 & 23,184 & 17,948 & $|0,29|$ & 30,055 \\
\hline Establishments & 7334 & 7334 & 4166 & 3168 & 1913 & 5421 \\
\hline Treated establ. & 1174 & 1174 & 366 & 808 & 169 & 1005 \\
\hline
\end{tabular}

Notes: Reported coefficients are treatment effects on the treated establishments from weighted linear difference-in-differences estimations. Weights are retrieved from entropy balancing. The dependent variable in column ( $\mathrm{I}$ ) is alignment to collectively bargained wages, in column (2) remuneration exceeding collectively bargained wages, and in columns (3) to (6) participation in any kind of collective bargaining (CB). Control variables as in columns (I) and (2) of Table 5 . Cluster robust standard errors are in parentheses (cluster = establishment). Asterisks indicate significance levels: $* p<0.1, * * p<0.05$ and $*_{* *}^{* *}<0.01$.

Source: IAB Establishment Panel 20 I I-2016, weighted analysis sample after entropy balancing.

collective bargaining could also be affected by the minimum wage if employers now align their wage levels to the legal minimum wage and no longer to collectively bargained wages (Ellguth and Kohaut, 2016). However, the estimates are insignificant and do not suggest that the minimum wage influenced the alignment to collectively bargained wages.

Column (2) of Table 8 looks at wage setting that exceeds collectively bargained wage levels. As pointed out by Jung and Schnabel (2011), collectively bargained wages are only a lower bound for the respective firms and a substantial fraction of plants exceed such wage levels by paying an additional wage premium. However, our treatment effects of the minimum wage are very small and insignificant in this respect, suggesting that such wage premiums on top of the collectively bargained wage rather concern the upper end of the wage distribution but not the minimum wage workers.

Columns (3) to (6) of Table 8 display effect heterogeneities for participation in any kind of collective bargaining (as in Table 5) split by western and eastern Germany and by firms with and without a works council. ${ }^{13}$ The results are insignificant but suggest that the slight decrease in bargaining coverage is rather driven by workplaces in western Germany and plants that have a works council. ${ }^{14}$ A possible explanation for the absence of a moderating effect of works councils could be that strategic decisions concerning wages go beyond the competencies of works councils. Moreover, these kinds of establishments in the west and with the presence of a works council have a much larger potential to opt out of collective bargaining contracts since the average coverage rates are still at a much higher level at these workplaces. 


\section{Conclusion}

The introduction of the new statutory minimum wage on 1 January 2015 is a large-scale experiment for the German labour market. While most of the literature concentrates on the effects of the new minimum wage on wages and employment (Bossler, 2016; Bossler and Gerner, 2016; vom Berge et al., 2016), we present the first evidence on how the minimum wage relates to major institutions of industrial relations such as collective bargaining. The minimum wage was introduced against a falling trend in collective bargaining coverage and the government aimed at strengthening the German model of social partnership between employers and unions. In our analysis, we first look at how such institutions of industrial relations relate to the establishment-level bite of the minimum wage, and second, we look at how the minimum wage influenced participation in collective bargaining.

Descriptive regression results demonstrate that the bite of the minimum wage, which was measured in 2014, is negatively correlated with industrial relations. Firms with a works council and firms covered by collective bargaining are less likely to be affected. This negative relationship is much stronger in eastern Germany but it is also significant in western Germany even after controlling for a large number of establishment characteristics.

When we analyse the influence of the minimum wage introduction on collective bargaining participation, we use a difference-in-differences approach in which the counterfactual control group is constructed from an entropy balancing procedure. The entropy balancing ensures that the control group closely resembles the treatment group especially with respect to pre-treatment levels and trends of the outcome variables, which is a crucial assumption for difference-in-differences estimation.

The results reveal a slight decrease in collective bargaining participation of treated establishments. Although the effect falls short of conventional significance levels, it increases over time and shows a plausible effect size implying a decrease in the range between one and two percentage points. This effect size closely matches the average yearly decline in the participation rate, which was about $1 \%$ over the last 20 years among all establishments in the market. Our effect should be interpreted for the subgroup of treated establishments that show an additional one to two percentage point decline in the course of the introduction of the minimum wage.

When we disentangle the effect into establishments that join and leave collective bargaining, we observe a statistically significant probability that an affected establishment opts out of collective bargaining contracts. However, we also observe a small positive probability for affected establishments to join bargaining contracts in the course of the introduction of the minimum wage. Since the latter effect falls short of significance and is dominated by firms leaving collective bargaining, our net effect is a slight reduction in bargaining participation. When we investigate further effect heterogeneities, the results show that works councils cannot mitigate this decreasing participation in collective bargaining. While works councils should have an interest in supporting participation in collective bargaining, the choice of bargaining seems to be a decision of the employer, which goes beyond the competencies of works councils. 
The result that a significant fraction of affected firms leave collective bargaining suggests that the minimum wage has a small substitutive mechanism when it comes to collective bargaining as a central institution of industrial relations in Germany. This substitutive mechanism can be explained by lowered marginal returns from collective bargaining, but the minimum wage may also constitute a substitutive norm replacing the traditional norm of collectively bargained wages. This result implies that the minimum wage should not be interpreted as an institution that strengthens the German tariff autonomy as proposed by the government in its official justification of the minimum wage legislation.

As our data on collective bargaining participation are collected in the third quarters of 2015 and 2016, the presented effects represent a reaction within a two-year period after the minimum wage was introduced. While a two-year period seems sufficient to decide on how to bargain over wages, future research may consider an even longer time period. However, very long-run effects are difficult to identify given the strict assumptions of conventional empirical strategies.

\section{Acknowledgements}

We acknowledge helpful comments by the participants at workshops in Bonn, Nuremberg, Potsdam, and at the 2017 annual conference of the Southern Economic Association. We are particularly thankful for comments of Bernhard Boockmann, Friedrich Buttler, Andreas Knabe and an anonymous referee.

\section{Declaration of conflicting interests}

The authors declared no potential conflicts of interest with respect to the research, authorship, and/ or publication of this article.

\section{Funding}

The authors received no financial support for the research, authorship, and/or publication of this article.

\section{Notes}

1. In the data, we observe 'establishments' as units of analysis, but use 'plants' and 'workplaces' synonymously.

2. The survey also asks establishments whether wages were already adjusted within the last 12 month in anticipation of the introduction of the minimum wage. It covers the period between the German general election in autumn 2013 and the period of the survey, which was conducted from June to September 2014. Ten per cent of the employers in our sample claim to have adjusted wages in anticipation of the introduction of the minimum wage. Since these establishments may contaminate the treatment assignment of our empirical analysis (Bossler and Gerner, 2016), we excluded all these establishments in a robustness check but our results remain unchanged.

3. These results are fully robust when we restrict the sample to establishments with at least five employees. This is an important robustness check since employees only have the legal right to implement a works council when the establishment has at least five permanent employees. If anything, the average partial effects of collective agreements slightly increase in size 
compared with column (1) of Table 2: -0.12 for industry-level contracts, -0.14 for firm-level contracts, -0.07 for alignment and -0.06 for works councils.

4. When we estimate effects on the proportion of affected employees from truncated regressions instead of using OLS or fractional probit, the results remain largely robust, but the estimates turn insignificant for firm-level bargaining. Since truncated regression exploits variation from the intensive margin only, this additional result suggests that some of the results of Table 3 (especially concerning firm-level bargaining) are rather driven by the establishment-level probability to be affected by the minimum wage than by the proportion of affected employees within affected establishments. This presumption is supported by a Tobit estimation, where both, the intensity and the incidence effect, are considered - as in OLS estimates - but with the advantage that censored estimates allow the elimination of potential biases. The Tobit estimation presents significant effects, also for firm-level bargaining contracts.

5. This procedure requires information from the pre-treatment period 2011-2014, and hence, it reduces the sample size to all establishments that are observed in the years from 2011 to 2014.

6. To show that there is sufficient variation in the outcome variables over time, Table A1 in the Appendix presents transition matrices for participation in any kind of collective bargaining. Between 2014 and 2015, as well as between 2014 and 2016, we observe establishments that enter or opt out of bargaining contracts.

7. The two effects would exactly add up if there were no switches between the two types of bargaining.

8. We cannot match on the very same trends in wages. In the absence of wage differences before the introduction of the minimum wage, no wage gap remains that would allow for significant wage effects of the minimum wage. This is the case theoretically and we observe the same result from our data. To equalize pre-treatment trends, we instead follow Bossler and Gerner (2016) and model the trend divergence from parametric treatment group-specific trends.

9. In fact, we use the same weights as in columns (5) and (6) of Table 4.

10. The sample size is reduced in Table 6 because of a substantial number of workplaces that do not report information on wages. However, the number of treated establishments remains unchanged.

11. Nevertheless, our results concerning effects on bargaining participation are robust to all three specifications.

12. We record a few changes in and out of bargaining in the years 2011-2014. As we do not classify these establishments in either of the two samples, the sample size slightly reduces. However, the effects are fully robust when we restrict the sample to firms with and without bargaining contracts only from the information of 2014.

13. The results are robust when we conduct estimations using treatment effect interactions instead of separate regressions.

14. Since employees only have the right to organize themselves in a works council when there are at least five permanent employees, we re-estimate the respective heterogeneity on works councils for a subsample of firms with at least five employees. All our regression results remain fully robust to this additional restriction, and hence, this robustness check does not yield any further insights.

\section{References}

Addison JT, Bryson A, Teixeira P et al. (2011) Slip sliding away: Further union decline in Germany and Britain. Scottish Journal of Political Economy 58: 490-518. 
Addison JT, Teixeira P, Evers K et al. (2014) Indicative and updated estimates of the collective bargaining premium in Germany. Industrial Relations 53: 125-156.

Addison JT, Teixeira P, Evers K et al. (2016) Is the erosion thesis overblown? Alignment from without in Germany. Industrial Relations 55: 415-443.

Addison JT, Teixeira P and Zwick T (2010) German works councils and the anatomy of wages. Industrial and Labor Relations Review 63: 247-270.

Aghion P, Algan Y and Cahuc P (2011) Civil society and the state: The interplay between cooperation and minimum wage regulation. Journal of the European Economic Association 9: $3-42$.

Apel H, Bachmann R, Bender S et al. (2012) Arbeitsmarktwirkungen der Mindestlohneinführung im Bauhauptgewerbe. Journal for Labour Market Research 45: 257-277.

Avouyi-Dovi S, Fougere D and Gautier E (2013) Wage rigidity, collective bargaining, and the minimum wage: Evidence from French agreement data. The Review of Economics and Statistics 95: 1337-1351.

Bellmann L, Bossler M, Gerner HD et al. (2015) Reichweite des Mindestlohns in deutschen Betrieben. IAB-Kurzbericht, 6/2015, Nuremberg.

Bossler M (2016) Mindestlohn in Deutschland, Großbritannien und in den USA. Wirtschaftsdienst 96: 422-425.

Bossler M (2017) The rise in orientation at collective bargaining without formal contract. LASER Discussion Paper No. 103, University of Erlangen-Nuremberg.

Bossler M and Gerner HD (2016) Employment effects of the new German minimum wage: Evidence from establishment-level micro data. IAB Discussion Paper 10/2016, Nuremberg.

Brenke K and Müller KU (2013) Gesetzlicher Mindestlohn: Kein verteilungspolitisches Allheilmittel. DIW Wochenbericht 49/2017: 3-17.

Dittrich M, Knabe A and Leipold K (2014) Spillover effects of minimum wages in experimental wage negotiations. CESifo Economic Studies 60: 780-804.

Ellguth P and Kohaut S (2016) Tarifbindung und betriebliche Interessenvertretung. Ergebnisse aus dem IAB-Betriebspanel 2015. WSI-Mitteilungen 69: 283-291.

Ellguth P, Gerner HD and Stegmaier J (2014a) Wage effects of works councils and opening clauses: The German case. Economic and Industrial Democracy 35: 95-113.

Ellguth P, Kohaut S and Möller I (2014b) The IAB Establishment Panel: Methodological essentials and data quality. Journal for Labour Market Research 47: 27-41.

Falck O, Knabe A, Mazat A et al. (2013) Mindestlohn in Deutschland: Wie viele sind betroffen? ifo Schnelldienst 66: 68-73.

Federal Government (2014) Entwurf eines Gesetzes zur Stärkung der Tarifautonomie. Deutscher Bundestag, Drucksache 18/1558. Available at: http://dip21.bundestag.de/dip21/ btd/18/015/1801558.pdf (accessed 9 February 2018).

Fischer G, Janik F, Müller D et al. (2009) The IAB Establishment Panel: Things users should know. Journal of Applied Social Science Studies 129: 133-148.

Hainmueller J (2012) Entropy balancing for causal effects: A multivariate reweighting method to produce balanced samples in observational studies. Political Analysis 20: 25-46.

Hainmueller J and Xu Y (2013) ebalance: A Stata package for entropy balancing. Journal of Statistical Software 54(7): 1-18.

Heumer M, Lesch H and Schröder C (2013) Mindestlohn, Einkommensverteilung und Armutsrisiko. IW-Trends 1.

Hübler O and Jirjahn U (2003) Works councils and collective bargaining in Germany: The impact on productivity and wages. Scottish Journal of Political Economy 50: 1-21. 
Jirjahn U (2017) Works councils and collective bargaining in Germany: A simple theoretical extension to reconcile conflicting empirical findings. Journal of Institutional and Theoretical Economics 173: 322-346.

Jung S and Schnabel C (2011) Paying more than necessary? The wage cushion in Germany. Labour 25: 182-197.

Kalina T and Weinkopf C (2013) Niedriglohnbeschäftigung 2011. IAQ Report, 2013-01.

Knabe A, Schöb R and Thum M (2014) Der flächendeckende Mindestlohn. Perspektiven der Wirtschaftspolitik 15: 133-157.

Müller S (2012) Works councils and establishment productivity. Industrial and Labor Relations Review 65: 880-898.

Oberfichtner M (2016) Works council introductions in Germany: Do they reflect workers' voice? Economic and Industrial Democracy. Epub ahead of print 9 May 2016. DOI: $10.1177 / 0143831 X 16645199$

Oberfichtner M and Schnabel C (2017). The German model of industrial relations: (Where) Does it still exist? LASER Discussion Paper No. 104, University of Erlangen-Nuremberg.

vom Berge P, Kaimer S, Copestake S et al. (2016) Arbeitsmarktspiegel: Entwicklungen nach Einführung des Mindestlohns (Ausgabe 1). IAB-Forschungsbericht 01/2016, Nuremberg.

\section{Author biographies}

Lutz Bellmann is a professor of labour economics at the University of Erlangen-Nuremberg and head of the research department Establishments and Employment at the Institute for Employment Research (IAB). His research interests focus on wages structures and employment dynamics, vocational education and training. Recent publications include, with HD Gerner and R Upward, 'Job and worker turnover in German establishments', The Manchester School (2017); and with $\mathrm{M}$ Bossler, HD Gerner and $\mathrm{O}$ Hübler, 'Training and minimum wages: First evidence from the introduction of the minimum wage in Germany', IZA Journal of Labor Economics 6: 1-22 (2017).

Mario Bossler is head of the working group Minimum Wages and a post-doctoral researcher at the Institute for Employment Research (IAB). His research interests focus on minimum wages and labour market institutions. Among his recent publications are, with S Broszeit, 'Do minimum wages increase job satisfaction? Micro data evidence from the new German minimum wage', Labour 31(4): 480-493 (2017); and 'Employment expectations and uncertainties ahead of the new German minimum wage', Scottish Journal of Political Economy 64(4): 327-348 (2017).

Hans-Dieter Gerner is a professor for quantitative methods in business and economics at the Nuremberg Institute of Technology Georg Simon Ohm. His research interests are in applied empirical labour and personnel economics. Recent publications include, with L Bellmann and R Upward, 'Job and worker turnover in German establishments', The Manchester School (2017); and with L Bellmann and MC Laible, 'The German labour market puzzle in the Great Recession', in: P Askenazy et al. (eds) Productivity Puzzles across Europe, pp. 187-235 (Oxford University Press, 2016).

Olaf Hübler is a Professor Emeritus for Empirical Economics at the Leibniz University of Hannover. His research interests are in applied micro-econometrics and labour economics. Among his recent publications are 'Health and weight', Economics and Human Biology 26: 96-111 (2017); and with T Herrmann, L Menkhoff and U Schmidt, 'Allais for the poor', Journal of Risk and Uncertainty 54(2): 129-156 (2017). 


\section{Appendix I}

Table Al. Descriptive transition matrices.

Panel (a): Transitions between 2014 and 2015 .

\begin{tabular}{|c|c|c|c|c|c|c|}
\hline & & \multicolumn{4}{|l|}{2015} & \multirow[t]{2}{*}{ Total in 2014} \\
\hline & & $\begin{array}{l}\text { Without any } \\
\text { bargaining } \\
\text { coverage }\end{array}$ & Alignment & $\begin{array}{l}\text { Ind.-level } \\
\text { bargaining }\end{array}$ & $\begin{array}{l}\text { Firm-level } \\
\text { bargaining }\end{array}$ & \\
\hline \multirow[t]{8}{*}{2014} & Without any & 2598 & 574 & 58 & 19 & 3249 \\
\hline & $\begin{array}{l}\text { bargaining } \\
\text { coverage }\end{array}$ & 80.0 & 17.7 & 1.8 & 0.6 & 100 \\
\hline & Alignment & 869 & 2214 & 167 & 51 & 3302 \\
\hline & & 26.3 & 67.1 & 5.1 & 1.6 & 100 \\
\hline & Ind.-level & 77 & 199 & 3171 & 83 & 3530 \\
\hline & bargaining & 2.2 & 5.6 & 89.8 & 3.4 & 100 \\
\hline & Firm-level & 24 & 64 & 76 & 500 & 664 \\
\hline & bargaining & 3.6 & 9.6 & 11.5 & 75.5 & 100 \\
\hline
\end{tabular}

Panel (b): Transitions between 2014 and 2016.

\begin{tabular}{|c|c|c|c|c|c|c|}
\hline & & \multicolumn{4}{|l|}{2016} & \multirow[t]{2}{*}{ Total in 2014} \\
\hline & & $\begin{array}{l}\text { Without any } \\
\text { bargaining } \\
\text { coverage }\end{array}$ & Alignment & $\begin{array}{l}\text { Ind.-level } \\
\text { bargaining }\end{array}$ & $\begin{array}{l}\text { Firm-level } \\
\text { bargaining }\end{array}$ & \\
\hline \multirow[t]{8}{*}{2014} & Without any & 2188 & 545 & 77 & 25 & 2935 \\
\hline & $\begin{array}{l}\text { bargaining } \\
\text { coverage }\end{array}$ & 77.2 & 19.2 & 2.7 & 0.9 & 100 \\
\hline & Alignment & 760 & 1870 & 213 & 60 & 2903 \\
\hline & & 26.2 & 64.4 & 7.3 & 2.1 & 100 \\
\hline & Ind.-level & 99 & 218 & 2679 & 86 & 3082 \\
\hline & bargaining & 3.2 & 7.1 & 86.9 & 2.8 & 100 \\
\hline & Firm-level & 24 & 76 & 91 & 392 & 583 \\
\hline & bargaining & 4.2 & 13.0 & 15.6 & 67.2 & 100 \\
\hline
\end{tabular}

Notes: Descriptive transitions between bargaining regimes in absolute numbers and in per cent. Panel (a) displays transitions from 2014 to 2015 and Panel (b) displays transitions from 2014 to 2016. Source: IAB Establishment Panel 20I4-20I6, analysis sample. 